\title{
KETERKAITAN PERIODISITAS CURAH HUJAN DI DAERAH PESISIR DAN PEGUNUNGAN PROVINSI JAWA TIMUR DENGAN VARIABILITAS CUACA SKALA GLOBAL DAN REGIONAL
}

\author{
Relationship of Rainfall Periodicity in Coastal dan Mountain Areas of East \\ Java Province with Global and Regional Scale Weather Variability
}

\author{
Adikusuma Kenangdjatu Bimaprawira ${ }^{1)}$, Hasti Amrih Rejeki ${ }^{2)}$ \\ 1) BMKG UPT Stasiun Meteorologi Utarom Kaimana. Jalan Utarom Airport, Kab. Kaimana, 98654. \\ 2) Sekolah Tinggi Meteorologi Klimatologi dan Geofisika. Jalan Perhubungan I No. 5, Pondok Betung, \\ Pondok Aren, Kota Tangerang Selatan, 15221. \\ *E-mail: adikusumakb@outlook.com
}

\begin{abstract}
Intisari
Jawa Timur merupakan wilayah yang memiliki variasi curah hujan yang dipengaruhi oleh fenomena cuaca global dan regional seperti Dipole Mode, El Nino Southern Oscillation (ENSO), Intertropical Convergence Zone, Madden Julian Oscillation, dan monsun. Topografi yang beragam juga menjadi faktor yang memengaruhi curah hujan di daerah Jawa Timur. Berbagai indeks digunakan untuk melihat aktivitas-aktivitas fenomena cuaca tersebut, seperti DMI untuk aktivitas Dipole Mode, NINO 3.4 untuk aktivitas ENSO, Indeks RMM untuk aktivitas MJO, WNPMI dan, AUSMI untuk aktivitas monsun. Pada penelitian ini digunakan analisis spektral dengan menggunakan metode Fast Fourier Transform untuk melihat periodisitas indeks masing-masing terhadap periodisitas curah hujan dari data 11 pos hujan yang terbagi menjadi 6 pos hujan daerah pesisir dan 5 pos hujan daerah pegunungan. Hasil dari penyeragaman periodisitas fenomena cuaca dengan curah hujan antara lain Dipole Mode (periodisitas 18 bulan), ENSO (periodisitas 18 dan 40 bulan), dan MJO (periodisitas 2 dan 3 bulan). Fenomena yang memengaruhi curah hujan di daerah pesisir maupun pegunungan secara dominan adalah fenomena monsun dengan diikuti ITCZ. Fenomena lain yang memengaruhi di daerah pesisir antara lain dominan MJO, serta fenomena ENSO dan Dipole Mode yang memengaruhi daerah Lamongan, Bunder, dan P3GI dengan kecenderungan lebih kuat pada fenomena Dipole Mode. Sementara itu, fenomena yang memengaruhi hujan di daerah pegunungan secara dominan adalah ENSO. Adapun fenomena lain yang memengaruhi hujan di daerah pegunungan antara lain fenomena MJO di daerah Tosari, serta daerah Kebon Teh Wonosari yang memiliki kecenderungan dipengaruhi oleh fenomena Dipole Mode meskipun pengaruhnya tidak signifikan.
\end{abstract}

Kata Kunci: Periodisitas, Curah Hujan, Pesisir, Pegunungan

\begin{abstract}
East Java is a region whose variations in rainfall are influenced by global and regional weather phenomena such as Dipole Mode, El Niño Southern Oscillation (ENSO), Intertropical Convergence Zone, Madden Julian Oscillation, and monsoons. Diverse topography is also a factor affecting rainfall in the area of East Java. Various indices are used to observe the activities of the weather phenomenon, such as DMI for Dipole Mode activities, NINO 3.4 for ENSO activities, RMM Index for MJO activities, as well as WNPMI and AUSMI for monsoon activities. In this study, spectral analysis was used by utilizing the Fast Fourier Transform method to see the periodicity of each index against the periodicity of rainfall from the 11 rainwater data points, which were divided into 6 coastal data points and 5 mountainous data points. Uniformity of weather phenomena with rainfall result among others Dipole Mode (18 months periodicity), ENSO (18 and 40-month periodicity), and MJO (2 and 3-month periodicity). Phenomena that affect rainfall in coastal and mountainous areas predominantly are monsoon, followed by ITCZ. Other phenomena affecting the coastal area include MJO dominant, and the ENSO and Dipole Mode phenomena that affect the Lamongan, Bunder, and P3GI regions with a stronger tendency to the Dipole Mode phenomenon. Another phenomenon that influences rain in the mountainous area is dominantly ENSO, while other phenomena include MJO phenomena in the Tosari area and Kebon Teh Wonosari region which has a tendency to be influenced by the Dipole Mode phenomenon despite the insignificant effect.
\end{abstract}

Keywords: Periodicity, Rainfall, Coastal, Mountain 


\section{PENDAhULUAN}

Wilayah Provinsi Jawa Timur memiliki luas 48.039,14 $\mathrm{km}^{2}$ dengan batas-batas sebelah utara Laut Jawa, sebelah timur Selat Bali, sebelah selatan Samudera Hindia, dan sebelah barat berbatasan dengan Provinsi Jawa Tengah. Secara astronomis, Provinsi Jawa Timur terletak antara $111.0^{\circ}-114.1^{\circ} \mathrm{BT}$ dan $7.2^{\circ}-8.8^{\circ} \mathrm{LS}$. Provinsi Jawa Timur memiliki curah hujan rata-rata 1.900 $\mathrm{mm}$ per tahun dengan suhu rata-rata berkisar antara $21-34{ }^{\circ} \mathrm{C}$. Variabilitas cuaca di Jawa Timur dipengaruhi oleh fenomena global dan regional. Fenomena global yang dimaksud adalah El Nino dan La Nina, Dipole Mode dan Maddem Jullian Oscillation. Monsun, dan ITCZ menjadi beberapa faktor cuaca regional yang berpengaruh terhadap cuaca/iklim di daerah Jawa Timur (USAID, 2018).

Fenomena ENSO merupakan fenomena variasi suhu muka laut dan atmosfer di daerah Pasifik Tengah. Fenomena ini memiliki siklus waktu selama 2 hingga 7 tahun (WMO, 2014). Fenomena ENSO memengaruhi keadaan curah hujan di daerah Jawa Timur. Pada fase El Nino, estimasi intensitas curah hujan cenderung lebih rendah bila dibandingkan dengan tahun normal di Provinsi Jawa Timur secara keseluruhan (Darajat et al.,2014). Pada saat fase La Nina, curah hujan di Pulau Jawa meningkat, termasuk beberapa titik di Jawa Timur (Mulyana, 2002).

Fenomena MJO memiliki rentang waktu siklus selama 30-60 hari. Fenomena ini bergerak dari barat ke timur di daerah ekuator (Madden dan Julian, 1971). Fenomena MJO sendiri dapat meningkatkan aktivitas konvektif di daerah Indonesia, yang dapat memacu adanya peningkatan curah hujan di Indonesia (Hermawan, 2010).

Fenomena Dipole Mode dapat memengaruhi sebagian daerah Indonesia. Perubahan suhu permukaan laut di Samudra Hindia sangat memengaruhi pola curah hujan di Indonesia. Pola siklus ini dimana periode Dipole Mode sendiri memiliki waktu kurang lebih 1-4 tahun (Yuggotomo \& Ihwan, 2014). Sementara, penelitian lain juga mengemukakan bahwa waktu periode Dipole Mode sendiri kurang lebih 1-3 tahun (Hermawan, 2007).

Inter Tropical Convergence Zone atau ITCZ merupakan daerah tekanan rendah yang memanjang dari barat ke timur dengan posisi selalu berubah mengikuti pergerakan matahari ke utara dan selatan khatulistiwa. Posisi ITCZ saat berada di utara, ekuator, maupun selatan ekuator memengaruhi curah hujan di wilayah Indonesia. Posisi ITCZ berada paling selatan ekuator saat Januari dasarian ke III. Pada bulan ini, wilayah Indonesia umumnya mengalami puncak musim hujan. Beberapa daerah memiliki intensitas curah hujan yang tinggi. Wilayah Indonesia bagian barat saat ITCZ berada paling selatan ekuator, cenderung mendapatkan intensitas curah hujan tertinggi selama periode musim hujan. Jawa Timur menjadi salah satu daerah yang terpengaruh dari fenomena ITCZ yang aktif di bulan Januari (Irjayanti et al.,2015).

Beberapa fenomena cuaca di atas merupakan siklus yang dapat terjadi kembali. Penggunaan metode analisis perhitungan dapat dilakukan untuk melihat suatu pola cuaca pada suatu daerah. Salah satunya dengan menggunakan metode analisis spektral. Penggunaan analisis spektral ini telah digunakan oleh beberapa penelitian untuk menentukan pola cuaca di suatu daerah. Beberapa penelitian juga menggunakan analisis spektral dengan metode Fast Fourier Transform (FFT) untuk mengkaji pola hujan berdasarkan periodisitas tertinggi. Misalnya, pada penelitian untuk menentukan perilaku hujan di beberapa daerah di Indonesia (Hermawan, 2011; Sagita et al., 2013; Karmilawati et al., 2014; Raharja dan Kadarsah, 2014).

Penelitian ini dilakukan untuk mengetahui keterkaitan antara periodisitas curah hujan di beberapa titik Provinsi Jawa Timur terhadap variabilitas cuaca skala global dan regional (ENSO, Dipole Mode, MJO, Monsun, dan ITCZ) dengan menggunakan analisis spektral dengan metode FFT. Wilayah Provinsi Jawa Timur terdapat topografi yang beragam, dalam penelitian ini di bagian utara Provinsi Jawa Timur sebagai perwakilan daerah pesisir dan pegunungan di daerah selatan Provinsi Jawa Timur sebagai wilayah perwakilan daerah pegunungan.

\section{METODE PENELITIAN}

Metode yang digunakan dalam penelitian ini adalah dengan menggunakan metode kuantitatif dan deskriptif. Metode kuantitatif didasarkan pada pengumpulan data-data berupa angka, dalam hal ini nilai indeks monsun yang diperoleh dari hasil pengolahan data variabilitas cuaca (ENSO, Dipole Mode, MJO, Monsun) dan data data curah hujan di 8 pos hujan terpilih (4 pos hujan daerah pesisir dan 4 pos hujan daerah pegunungan) serta 3 penakar hujan dari Stasiun Meteorologi Juanda, Stasiun Meteorologi Perak II dan Stasiun Klimatologi Malang. Model penelitian secara deskriptif berdasarkan pada interprestasi hasil periodigram dari indeks monsun, Indeks Nino 3.4, DMI dan RMM MJO dan curah hujan yang telah diproses dengan menggunakan metode Fast Fourier Transform.

Adapun rumus persamaan Fast Fourier Transform yang diadopsi dari penelitian Sagita dkk. (2013) adalah sebagai berikut,

$$
f(x)=a_{0} \sum_{p=1}^{\left(\frac{N}{2}\right)-1}\left[a_{n} \cos \left(\frac{2 \pi p t}{T}\right)+b_{n} \sin \left(\frac{2 \pi p t}{T}\right)\right]
$$




$$
\begin{gathered}
a_{0}=x \\
a_{n}=\frac{2\left[\sum x_{t} \cos \left(\frac{2 \pi p t}{T}\right)\right]}{T} \\
b_{n}=\frac{2\left[\sum x_{t} \sin \left(\frac{2 \pi p t}{T}\right)\right]}{T}
\end{gathered}
$$

dengan ao adalah koefisien a atau komponen a ke $\mathrm{n}$, $b_{n}$ adalah koefisien $b$ atau komponen $b$ ke $n$, $T$ adalah banyaknya data, $\mathrm{t}$ adalah waktu, dan $\mathrm{p}$ adalah periodik.

Persamaan deret Fourier di atas kemudian diinversi dari fungsi waktu (t) ke fungsi frekuensi $(\omega)$ untuk memperoleh persamaan Fast Fourier Transform sebagai berikut

$$
X=\int_{-\infty}^{\infty} x(t) e^{-i \omega t} d t
$$

Selanjutnya, nilai Power Spectral Density pada peridogram diperoleh dari:

$$
\operatorname{PSD}(\omega)=\frac{T}{2}\left(a_{p}^{2}+b_{p}^{2}\right)
$$

dengan $\omega$ adalah frekuensi.
Dari hasil periodigram tersebut akan diambil 3 puncak periode tertinggi dalam hasil grafik metode Fast Fourier Transform tersebut. Setelah memperoleh hasil 3 puncak periode, selanjutnya akan dilihat keseragaman antara hasil periodigram fenomena cuaca dan curah hujan. Apabila terdapat hasil yang memiliki periode yang sama dari fenomena cuaca terhadap periode curah hujan, maka indeks-indeks yang berhubungan dan curah hujan akan dikorelasikan untuk menentukan pengaruh mana yang lebih kuat melalui Korelasi Pearson. Selain itu, dilakukan juga studi karakteristik periodisitas dari fenomena Inter Tropical Convergence Zone (ITCZ) untuk melihat pengaruh di daerah pesisir maupun daerah pegunungan. Selanjutnya hasil dari pengolahan tersebut akan di interpretasi dan dianalisis pada pembahasan.

Data penelitian yang digunakan antara lain indeks Nino 3.4, indeks RMM MJO, indeks Dipole Mode, dan data angin zonal $850 \mathrm{mb}$ global bulanan dari ECMWF dengan resolusi $0.25^{\circ} \times 0.25^{\circ}$ untuk menentukan nilai indeks monsoon. Selain itu, data yang digunakan adalah data curah hujan dari 8 pos hujan, dan 3 dari UPT BMKG yang telah disebutkan sebelumnya.

Lokasi studi berada di wilayah Provinsi Jawa Timur. Lokasi penelitian tersebar di 11 titik; 6 titik pos hujan di bagian pesisir dan 5 titik pos hujan di daerah pegunungan. Periode waktu penelitian berlangsung mulai tahun 2009 hingga tahun 2018. Letak pos hujan yang digunakan dalam penelitian ini ditunjukkan pada Gambar 1. Profil lokasi dari masing-masing pos hujan ditunjukkan pada Tabel 1.

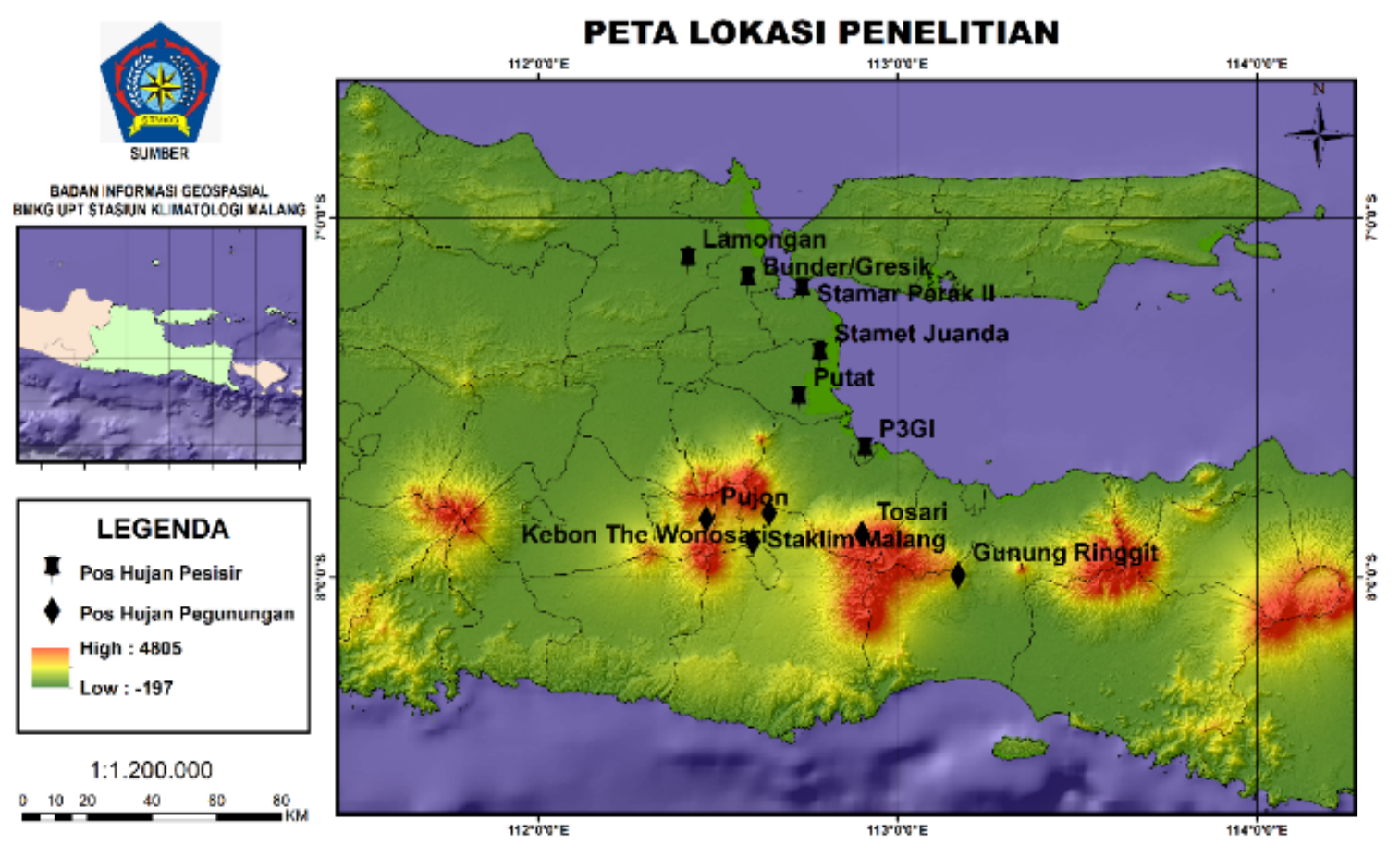

Gambar 1. Peta lokasi penelitian. 
Tabel 1. Profil lokasi pos hujan pesisir dan pegunungan.

\begin{tabular}{|c|c|c|c|c|c|}
\hline No & $\begin{array}{l}\text { Lokasi Pos } \\
\text { Hujan }\end{array}$ & Bujur & Lintang & $\begin{array}{l}\text { Elevasi } \\
(\mathrm{m})\end{array}$ & Klasifikasi \\
\hline 1 & Tosari & 112.90 & -7.88 & 1714 & \multirow{5}{*}{$\begin{array}{l}\text { Pos Hujan } \\
\text { Pegunungan }\end{array}$} \\
\hline 2 & $\begin{array}{l}\text { Kebun Teh } \\
\text { Wonosari }\end{array}$ & 112.64 & -7.82 & 957 & \\
\hline 3 & Pujon & 112.47 & -7.84 & 1090 & \\
\hline 4 & Staklim Malang & 112.60 & -7.90 & 550 & \\
\hline 5 & Gunung Ringgit & 113.17 & -7.99 & 688 & \\
\hline 6 & Lamongan & 112.42 & -7.12 & 22 & \multirow{6}{*}{ Pos Hujan Pesisir } \\
\hline 7 & Bunder /Gresik & 112.58 & -7.18 & 31 & \\
\hline 8 & Stamar Perak II & 112.74 & -7.21 & 17 & \\
\hline 9 & Stamet Juanda & 112.78 & -7.38 & 17 & \\
\hline 10 & P3GI & 112.91 & -7.65 & 8 & \\
\hline 11 & Putat & 112.73 & -7.51 & 10 & \\
\hline
\end{tabular}

\section{HASIL DAN PEMBAHASAN}

\subsection{Hasil Periodisitas Fenomena Cuaca}

Berdasarkan hasil analisis spektral menggunakan metode FFT terhadap Dipole Mode Index, terlihat puncak periode pertama berada pada periode 18 bulan. Periode puncak kedua berada pada periode 42 bulan, dan periode puncak ketiga berada pada periode 12 bulan, seperti yang digambarkan oleh Gambar 2.

Hasil analisis spektral menggunakan metode FFT terhadap Indeks NINO 3.4, seperti yang disajikan pada Gambar 3, menunjukkan bahwa puncak periode pertama berada pada periode 40 bulan. Periode puncak kedua berada pada periode 120 bulan. Periode puncak ketiga berada pada periode 18 bulan.

Hasil analisis spektral menggunakan metode FFT terhadap Indeks RMM 1 MJO periode tahun 2009-2018 pada Gambar 4 menunjukkan bahwa puncak periode pertama berada pada periode 45 hari. Periode puncak kedua berada pada periode 50 hari. Periode puncak ketiga berada pada periode 40 hari. Selanjutnya, hasil dari analisis spektral menggunakan metode FFT dari Indeks RMM 2 menunjukkan bahwa puncak periode pertama berada pada periode 45 hari, periode puncak kedua berada pada periode 60 hari, dan periode puncak ketiga berada pada periode 58 hari.

Hasil dari analisis spektral menggunakan metode FFT dari parameter West North Pacific Monsoon Index (WNPMI) dan Australian Monsoon Index (AUSMI) ditampilkan pada Gambar 5. Pada parameter West North Pacific Monsoon Index (WNPMI) menunjukkan bahwa puncak periode pertama berada pada periode 12 bulan. Periode puncak kedua berada pada periode 6 bulan. Periode puncak ketiga berada pada 18 bulan. Sedangkan, pada parameter Australian Monsoon Index (AUSMI) menunjukkan bahwa puncak periode pertama berada pada periode 12 bulan. Periode puncak kedua berada pada periode 6 bulan. Periode puncak ketiga tidak teridentifikasi.

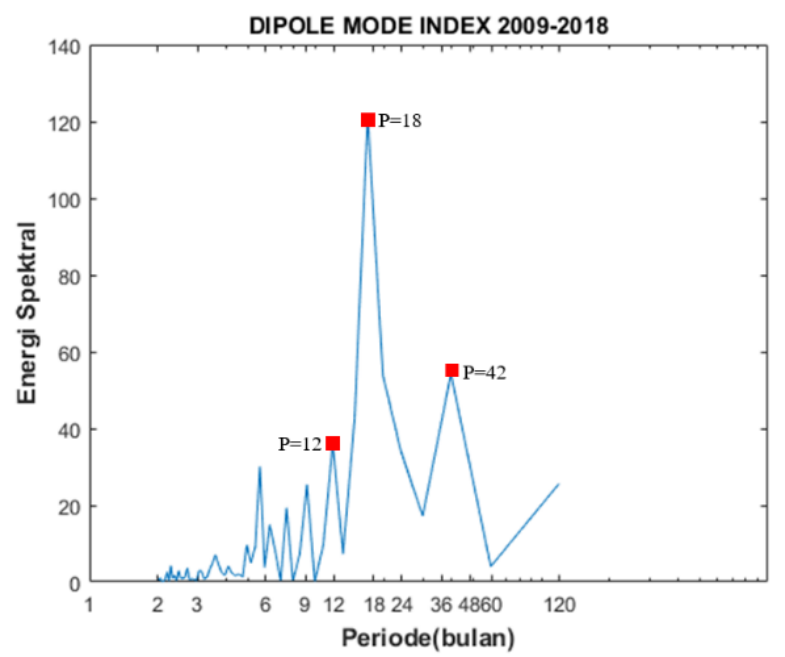

Gambar 2. Hasil analisis spektral FFT Dipole Mode Index. 


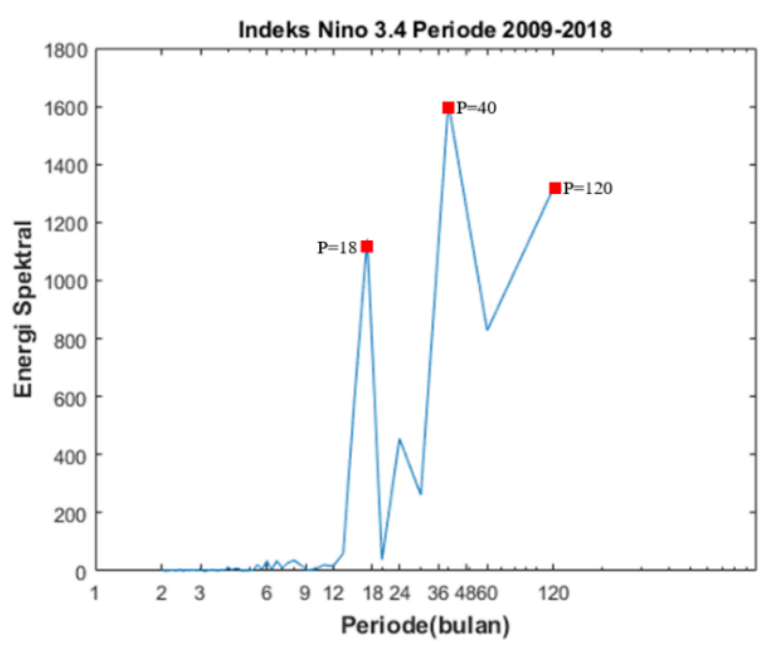

Gambar 3. Hasil analisis spektral FFT indeks NINO 3.4.

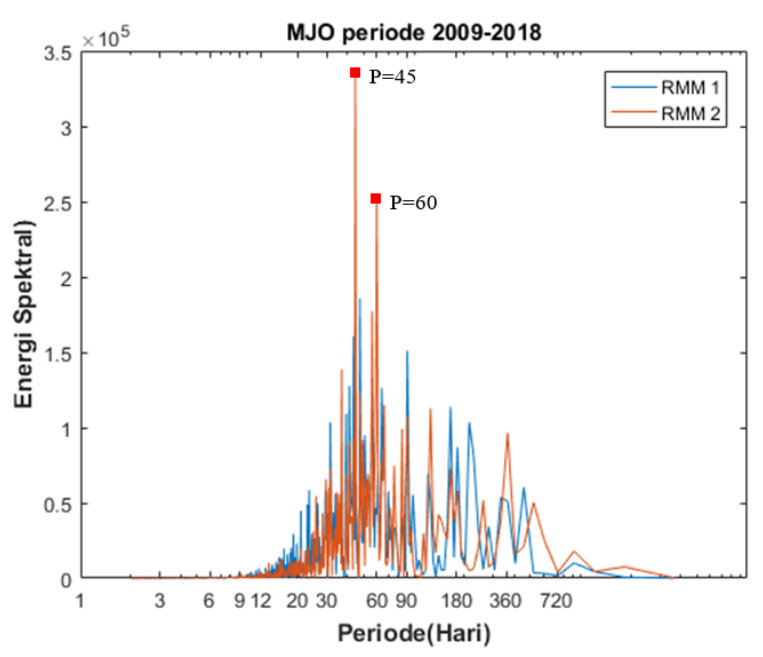

Gambar 4. Hasil analisis spektral FFT RMM 1 dan RMM 2 MJO.

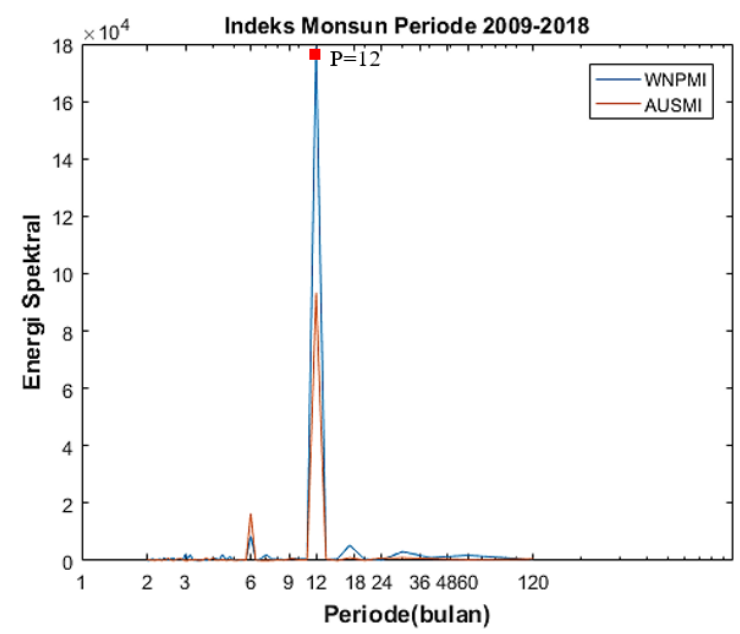

Gambar 5. Hasil analisis spektral FFT AUSMI dan WNPMI.

\subsection{Hasil Periodisitas Curah Hujan Pesisir}

Hasil analisis spektral dengan menggunakan metode Fast Fourier Transform data keenam pos hujan daerah pesisir ditampilkan dalam Gambar 6. Adapun hasil dari puncak periodisitas tiap pos hujan dijabarkan dalam Tabel 2.

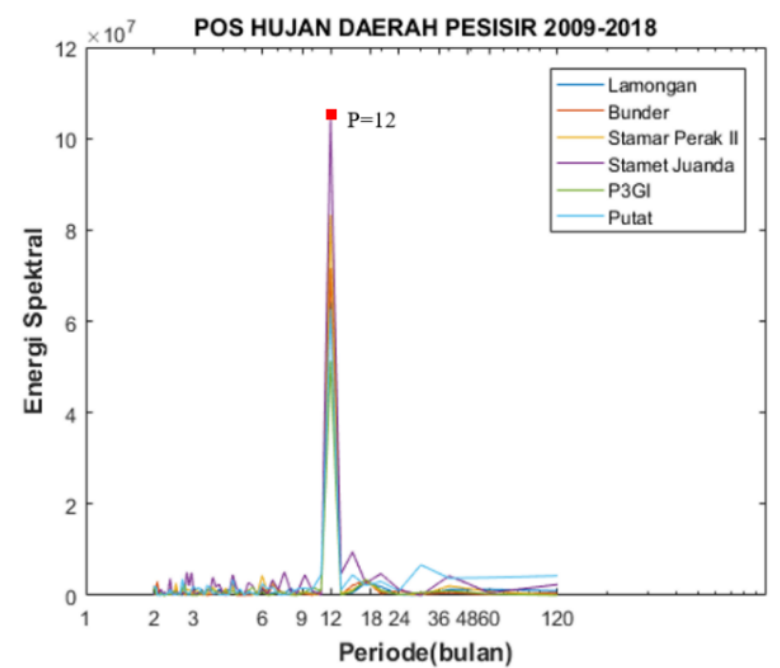

Gambar 6. Hasil analisis spektral FFT curah hujan daerah pesisir.

Secara umum, puncak periode pertama dari enam lokasi pos hujan di daerah pesisir Provinsi Jawa Timur pada Gambar 6 dan Tabel 2 menyatakan bahwa puncak periode pertama dari analisis spektral tersebut berada pada periode 12 bulan. Apabila kita melihat periode tersebut dengan fenomena dalam penelitian ini, maka dapat ditemukan kemiripan dengan hasil analisis spektral indeks monsun pada Gambar 5, dimana puncak periode analisis spektral indeks monsun berada pada periode 12 bulan.

Tabel 2. Hasil periodigram pos hujan pesisir.

\begin{tabular}{|c|c|c|c|}
\hline \multirow{2}{*}{ Pos Hujan } & \multicolumn{3}{|c|}{ Puncak Periode } \\
\cline { 2 - 4 } & $\begin{array}{c}\text { Periode } \\
\text { ke 1 }\end{array}$ & $\begin{array}{c}\text { Periode ke } \\
\mathbf{2}\end{array}$ & $\begin{array}{c}\text { Periode ke } \\
\mathbf{3}\end{array}$ \\
\hline Bunder & 12 & 18 & 2 \\
\hline Lamongan & 12 & 18 & 2 \\
\hline Putat & 12 & 30 & 15 \\
\hline P3GI & 12 & 18 & 3 \\
\hline $\begin{array}{c}\text { Stamet } \\
\text { Juanda }\end{array}$ & 12 & 15 & 3 \\
\hline $\begin{array}{c}\text { Stamar } \\
\text { Perak II }\end{array}$ & 12 & 6 & 3 \\
\hline
\end{tabular}


Periodisitas selanjutnya dari puncak periode kedua pada Gambar 6 memiliki nilai sebesar 18 bulan dengan lokasi di daerah Bunder, Lamongan, P3GI. Periode tersebut identik dengan tiga fenomena hasil analisis spektral Dipole Mode pada Gambar 2, dan ENSO pada Gambar 3.

Kedua hasil yang sama ini diuji dengan menggunakan Korelasi Pearson. Hasil korelasi dari DMI dan curah hujan pada pos hujan Bunder sebesar - 0.24 , pos hujan Lamongan sebesar -0.25, dan pos Hujan P3GI Pasuruan sebesar -0.23. Selanjutnya, hasil korelasi dari indeks NINO3.4 dan curah hujan pada pos hujan Bunder sebesar -0.16, pos hujan Lamongan sebesar -0.14, dan pos hujan P3GI Pasuruan sebesar -0.14 .

Hasil yang di dapat dari korelasi menunjukkan bahwa kedua korelasi tersebut berada pada posisi korelasi lemah, dengan tanda negatif menunjukkan bahwa apabila DMI dan Indeks NINO3.4 positif atau sedang aktif, maka akan berdampak pada curah hujan yang berkurang. Dalam kedua korelasi tersebut terhadap curah hujan, indeks Nino 3.4 memiliki korelasi yang lebih lemah dibandingkan DMI. Akibatnya, pengaruh dari kedua periode yang serupa memiliki kecenderungan pada Dipole Mode bila dibandingkan dengan ENSO. Hasil dari puncak periode kedua analisis spektral lainnya berasal dari pos hujan Putat dengan periode 30 bulan, Stasiun Meteorologi Juanda dengan periode 15 bulan, dan Stasiun Meterologi Perak II dengan periode 6 bulan.

Hasil puncak periode ketiga pada Gambar 6 memiliki lima hasil yang berbeda dari kesebelas lokasi tersebut. Hasil pertama adalah periode 3 bulanan dari pos hujan P3GI, Stasiun Meteorologi Juanda, dan Stasiun Meteorologi Perak II. Periode ini identik dengan fenomena MJO, hasil analisis spektral curah hujan selama 9 dasarian atau 3 bulanan dan diklasifikasikan sebagai fenomena MJO (Sagita et al., 2013). Hasil kedua puncak periode ketiga adalah periode 2 bulan dari pos hujan Bunder, Lamongan. Hasil ini identik dengan yang didapatkan pada analisis spektral RMM 2 MJO yang memiliki periode 60 harian atau 2 bulanan seperti pada gambar 4 . Hasil puncak periode ketiga lainnya yaitu periode 15 bulan di pos hujan Putat.

\subsection{Hasil Periodisitas Curah Hujan Pegunungan}

Hasil analisis spektral dengan menggunakan metode Fast Fourier Transform data kelima pos hujan daerah pegunungan ditampilkan dalam Gambar 7. Adapun hasil dari puncak periodisitas tiap pos hujan juga dijabarkan dalam Tabel 3.

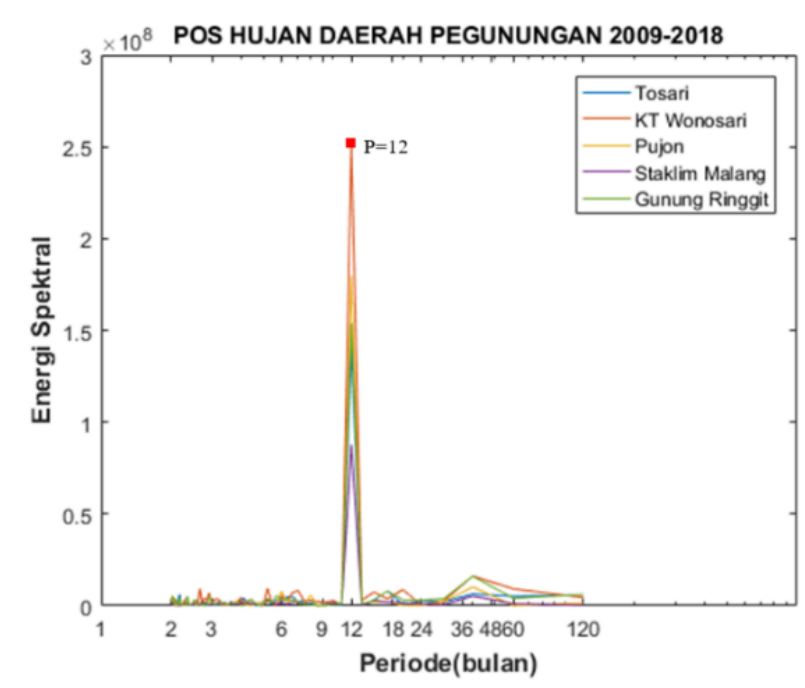

Gambar 7. Hasil analisis spektral FFT curah hujan daerah pegunungan.

Tabel 3. Hasil Periodigram pos hujan pegunungan.

\begin{tabular}{|c|c|c|c|}
\hline \multirow{2}{*}{ Pos Hujan } & \multicolumn{3}{|c|}{ Puncak Periode } \\
\cline { 2 - 4 } & $\begin{array}{c}\text { Periode } \\
\text { ke 1 }\end{array}$ & $\begin{array}{c}\text { Periode } \\
\text { ke 2 }\end{array}$ & $\begin{array}{c}\text { Periode } \\
\text { ke 3 }\end{array}$ \\
\hline Pujon & 12 & 40 & 6 \\
\hline Tosari & 12 & 16 & 2 \\
\hline $\begin{array}{c}\text { KT } \\
\text { Wonosari }\end{array}$ & 12 & 40 & 18 \\
\hline $\begin{array}{c}\text { Gunung } \\
\text { Ringgit }\end{array}$ & 12 & 40 & 18 \\
\hline $\begin{array}{c}\text { Staklim } \\
\text { Malang }\end{array}$ & 12 & 40 & 6 \\
\hline
\end{tabular}

Selanjutnya, puncak periode kedua pada Tabel 3 memiliki hasil yang beragam dari kelima lokasi tersebut. Hasil terbanyak pertama yaitu periode sebesar 40 bulan dengan lokasi pada pos hujan Pujon, Kebon Teh Wonosari, Gunung Ringgit dan Stasiun Klimatologi Malang. Periodisitas 40 bulan ini serupa dengan puncak periode ENSO melalui Indeks Nino 3.4 pada Gambar 3 dimana memiliki persamaan periode puncak 40 bulan. Hasil puncak periode ketiga lainnya yaitu periode 16 bulan di pos hujan Tosari.

Puncak periode ketiga pada Tabel 3 dari kelima lokasi memiliki hasil periode puncak 2 bulan pada pos hujan Tosari, periode puncak 6 bulan pada pos hujan Pujon dan Stasiun Klimatologi Malang, dan periode 18 bulan pada pos hujan Kebon Teh Wonosari dan Gunung Ringgit. Puncak periode analisis spektral dengan nilai sebesar 2 bulan identik dengan periode osilasi MJO yang telah dibahas sebelumnya pada subbab 3.2. 
Seperti pada subbab 3.2 tentang puncak periode 18 bulan, fenomena yang memengaruhi kedua pos hujan tersebut antara lain Dipole Mode dan ENSO. Oleh karena itu, perlu digunakan korelasi untuk mengetahui hasil mana yang lebih berpengaruh terhadap pos hujan yang memiliki periode yang sama.

Hasil korelasi DMI dengan curah hujan dan indeks NINO3.4 dengan curah hujan menunjukkan bahwa kedua korelasi tersebut berada pada posisi korelasi lemah. Hasil korelasi dari DMI dan curah hujan yaitu pada pos Hujan Kebon Teh Wonosari sebesar -0.25 , dan pos hujan Gunung Ringgit sebesar -0.22 . Selanjutnya, hasil korelasi dari indeks NINO3.4 dan curah hujan yaitu pada pos Hujan Kebon Teh Wonosari sebesar -0.11 dan pos hujan Gunung Ringgit sebesar -0.23.

Hasil ini serupa dengan hasil yang didapat pada subbab 3.2 yang menunjukkan bahwa apabila keadaan NINO3.4 aktif atau DMI positif, maka akan memengaruhi berkurangnya curah hujan dan sebaliknya. Kedua hasil korelasi dari kedua pos hujan tersebut tampak berbeda. Pada pos hujan Kebon Teh Wonosari memiliki kecenderungan dipengaruhi oleh Dipole Mode dibandingkan dengan ENSO. Pada pos hujan Gunung Ringgit, meskipun masih dipengaruhi oleh Dipole Mode, Fenomena ENSO tetap memiliki pengaruh yang dominan akibat hasil dari puncak periode kedua dari analisis spektral pos hujan Gunung Ringgit yang identik dengan hasil analisis spektral NINO3.4 pada Gambar 3.

\subsection{Pembahasan}

Hasil dari kedua periodisitas antara fenomena cuaca dan curah hujan di daerah pesisir Provinsi Jawa Timur menunjukkan fenomena monsun menjadi fenomena paling dominan yang memengaruhi curah hujan di daerah pesisir maupun daerah pegunungan Provinsi Jawa Timur. Fenomena cuaca monsun ini terjadi juga bersamaan dengan ada peristiwa ITCZ. Chao (2000) mengemukakan bahwa ada pergerakan lintang ITCZ dalam siklus tahunannya tidak selalu bertahap (Satiadi dan Adikusumah, 2012). Penelitian yang sama membuktikan terdapat kesesuaian lompatan ITCZ dengan fenomena monsun Indo-Australia yang secara bersamaan. Akibatnya, keberadaan ITCZ dengan monsun ini terkait dengan kondisi hujan di wilayah IndoAustralia dimana dapat mendeteksi awal musim hujan di wilayah Indo-Australia.

Pengaruh fenomena cuaca dominan lainnya terhadap periodisitas curah hujan di daerah pesisir Provinsi Jawa Timur adalah MJO. MJO memiliki pengaruh di hampir semua lokasi pos hujan di daerah pesisir. Selain fenomena cuaca dominan, terdapat fenomena cuaca lainnya yang memengaruhi beberapa pos hujan di daerah pesisir dengan lokasi di pos hujan Bunder Gresik,
Lamongan, dan P3GI, yaitu fenomena Dipole Mode. Namun, pengaruh dari fenomena ini cenderung kecil mengingat hasil dari korelasi antara DMI dengan curah hujan dan NINO3.4 dengan curah hujan pada subbab 3.1 hanya menghasilkan nilai korelasi yang kecil.

Pengaruh fenomena cuaca dominan lainnya dari periodisitas curah hujan di daerah pegunungan provinsi Jawa Timur tersebut adalah ENSO. ENSO sendiri memiliki pengaruh yang dominan pada pos hujan di daerah pegunungan Provinsi Jawa Timur. Disamping fenomena cuaca yang dominan, terdapat beberapa fenomena cuaca yang memengaruhi beberapa pos hujan di daerah pegunungan. Fenomena MJO hanya terjadi di pos hujan Tosari, dimana lokasi dari pos hujan Tosari sendiri masih berdekatan dengan daerah pesisir seperti pos hujan P3GI, dimana pos hujan P3GI juga terperngaruh oleh fenomena MJO. Selanjutnya, fenomena Dipole Mode memiliki pengaruh pada pos hujan Kebon Teh Wonosari, meskipun pengaruh dari Dipole Mode sendiri tidak signifikan, seperti pada pembahasan sebelumnya di daerah pesisir.

Pada penelitian ini sebagian besar penyeragaman antara periodisitas fenomena cuaca dengan curah hujan memiliki periodisitas yang seragam, tetapi masih terdapat beberapa hasil yang tidak memiliki keseragaman antara fenomena cuaca dengan curah hujannya, baik di daerah pesisir maupun daerah pegunungan. Daerah pesisir memiliki beberapa hasil lain yang tidak memiliki keseragaman dengan beberapa periodisitas fenomena cuaca dengan periodisitas di beberapa pos hujan, seperti pada pos hujan Putat, Stasiun Meteorologi Juanda, dan Stasiun Meteorologi Perak II. Pada hasil analisis periodisitas dari Stasiun Meteorologi Perak II, terdapat suatu fenomena lainnya yang berosilasi setiap 6 bulan. Penelitian lain mengemukakan bahwa terdapat hasil periodisitas 6 bulanan pada daerah Surabaya (Visa dan Harjupa, 2010). Namun, hasil periodisitas ini dianggap tidak signifikan sehingga tidak diklasifikasikan. Oleh karena itu, pada penelitian ini, periodisitas 6 bulan juga tidak diklasifikasikan. Stasiun Meteorologi Juanda dan pos hujan Putat memiliki periodisitas 15 bulanan, dimana terdapat ketidaksesuaian dengan penyeragaman antara periodisitas fenomena cuaca dengan curah hujan pada penelitian ini.

Daerah pegunungan juga memiliki beberapa hasil lain yang tidak memiliki keseragaman antara beberapa periodisitas fenomena cuaca dengan periodisitas di beberapa pos hujan seperti pada pos hujan Tosari, pos hujan Pujon, dan Stasiun Klimatologi Malang. Pada pos hujan Pujon dan Stasiun Klimatologi Malang, didapati suatu fenomena lainnya yang berosilasi setiap 6 bulan. Namun, hasil periodisitas 6 bulanan, atau yang dapat disebut juga Semi Annual Oscillation (SAO), 
pada daerah Malang dianggap tidak signifikan karena tidak memengaruhi hujan di daerah Malang, sehingga tidak diklasifikasikan (Visa, 2009). Oleh karena itu, pada penelitian ini, periodisitas 6 bulan juga tidak diklasifikasikan. Pos hujan Tosari juga mengalami hal yang sama, dimana periodisitas curah hujan bernilai 16 bulanan juga tidak memiliki keseragaman dengan fenomena cuaca pada penelitian ini. Berdasarkan hasil penelitian ini, perlu ada penelitian lanjutan untuk menganalisis periodisitas dengan data yang lebih lengkap, sehingga dapat ditelusuri apakah ada fenomena yang sama dengan periodisitas tersebut.

\section{KESIMPULAN}

Hasil dari analisis spektral menunjukkan bahwa pos hujan daerah pesisir maupun daerah pegunungan dominan mengalami periodisitas 12 bulan. Meskipun demikian, setiap lokasi memiliki karakteristik tersendiri. Daerah pesisir memiliki pola periodisitas 2 bulan (Bunder dan Lamongan), 3 bulan (P3GI, Stasiun Meteorologi Juanda, dan Stasiun Meteorologi Perak II), 6 bulan (Stasiun Meteorologi Perak II), 18 bulan (Bunder, Lamongan dan P3GI), 15 bulan (Stasiun Meteorologi Juanda dan Putat), dan 30 bulan (Putat). Sementara itu, daerah pegunungan memiliki pola periodisitas 2 bulan (Tosari), 6 bulan (Pujon dan Stasiun Klimatologi Malang), 16 bulan (Tosari), 18 bulan (Kebon Teh Wonosari dan Gunung Ringgit), 40 bulan (Pujon, Tosari, Kebon Teh Wonosari, Gunung Ringgit, dan Stasiun Klimatologi Malang).

Fenomena cuaca yang dominan, baik di daerah pesisir maupun daerah pegunungan Provinsi Jawa Timur, adalah fenomena monsun dengan diikuti oleh fenomena ITCZ. Selain itu fenomena dominan lainnya memengaruhi hujan di daerah pesisir adalah Fenomena MJO. Sementara itu, Fenomena ENSO dan Dipole Mode memengaruhi daerah Lamongan, Bunder, dan P3GI, dengan kecenderungan pada Fenomena Dipole Mode meskipun pengaruhnya kecil. Fenomena dominan lainnya di daerah pegunungan adalah fenomena ENSO. Adapun fenomena lainnya yang memengaruhi daerah pegunungan antara lain fenomena MJO di daerah Tosari, dan Fenomena Dipole Mode di daerah Kebon Teh Wonosari meskipun pengaruhnya tidak signifikan.

\section{DAFTAR PUSTAKA}

Chao, W.C., (2000). Multiple Quasi Equilibria of the ITCZ and the Origin of Monsoon Onset. Journal of the Atmospheric Sciences, 57, 641-651. doi: 10.1175/15200469(2001)058<2820:MQEOTI>2.0.CO;2
Hermawan, E., (2007). Penggunaan FFT dalam Analisis Kenormalan Curah Hujan di Sumatera Barat dan Selatan Khususnya Saat Kejadian Dipole Mode. Jurnal Meteorologi dan Geofisika, 8(2), 57-66. doi: 10.31172/jmg.v8i2.13.

Hermawan, E., (2010). Analisis Struktur Vertikal MJO Terkait dengan Aktivitas Super Cloud Clusters (SCCs) di Kawasan Barat Indonesia. Jurnal Sains Dirgantara, 8(1), 5766.

Hermawan, E., (2011). Peran Data Indeks Monsun Global dan IOD Terhadap Perilaku Curah Hujan di Beberapa Kawasan Indonesia. Prosiding Seminar Nasional Sains Atmosfer dan Antariksa, 57-66.

Irjayanti, P., Sulistya, W., dan Setiawan, A.M., (2015). Penjalaran ITCZ di Wilayah Indonesia Berdasarkan Data Satelit TRMM. (https://perpus.stmkg.ac.id/viewpdf.php?id=398).

Karmilawati, L., Hermawan, E., dan Utama, J.A., (2014). Pengaruh Indeks Monsun Global Terhadap Perilaku Curah Hujan di Tabing Sumatera Barat. Prosiding Seminar Sains Atmosfer, 289-299.

Madden, R. A., dan Julian, P.R., (1971). Description of global-scale circulation cells in the tropics with a 40-50 day period. Journal Atmospheric Science, 29, 11091123. doi: 10.1175/15200469(1972)029<1109:DOGSCC>2.0.CO;2.

Mulyana., E., (2002). Hubungan Antara ENSO dengan Variasi Curah Hujan di Indonesia. Jurnal Sains \& Teknologi Modifikasi Cuaca, 3, 1-4. doi: 10.29122/jstmc.v3i1.2153.

Raharja, A. B., dan Kadarsah, (2014). Pengaruh Indeks Monsun Indonesia Terhadap Curah Hujan di Sumatera Selatan. Seminar Sains Atmosfer 2014, 8-18.

Sagita, N., As'ari, dan Wandayantolis, (2013). Analisis Spektral Data Curah Hujan di Sulawesi Utara. Jurnal MIPA UNSRAT Online, $\quad 2, \quad 133-139 . \quad$ doi: 10.35799/jm.2.2.2013.3187.

https://ejournal.unsrat.ac.id/index.php/jmuo/ article/view/3187.

Satiadi, D., dan Adikusumah, N., (2012). ITCZ dan Monsun Indo-Australia. Prosiding Seminar Sains Atmosfer dan Aplikasinya, 77-83.

USAID. (2018). Laporan Kajian Kerentanan dan Risiko Iklim Provinsi Jawa Timur, USAID/Indonesia Office of Environment, Jakarta.

Visa, J., (2009). Analisis Ragam Osilasi Curah hujan di Probolinggo dan Malang Seminar Nasional Penelitian, Penerapan dan Pendidikan MIPA, 469-475.

Visa, J., dan Harjupa, W., (2010). Analisis Power Spectral Density (PSD) Curah Hujan di 
Wilayah Indonesia. Prosiding Seminar Penerbangan dan Antariksa, 68-76.

World Meteorological Organization, (2014). El Nino Southern Oscillation, World Meteorological
Organization:

Geneva. https://library.wmo.int/doc_num.php?explnu $\mathrm{m} \_\mathrm{id}=7888$. 